\title{
Aasavikaranam: An Ayurvedic Technique for Phytochemical Extraction by Microbial Maceration
}

\author{
Pillai Sangeetha $\mathrm{G}^{1}$, Yadav Yadevendra ${ }^{2 *}$, Sharma $\mathrm{Usha}^{3}$, Sharma Khemchand ${ }^{4}$ \\ ${ }^{1}$ PG Scholar, ${ }^{2}$ Assistant Prof, ${ }^{3}$ Associate Prof \& ${ }^{4}$ Professor and HOD, P G Deptt of RS \& BK, Uttarkhand Ayurved University, Rishikul Campus, \\ Haridwar, India 249401
}

DOI: $10.36348 /$ sijtcm.2020.v03i05.003

| Received: 03.04.2020 | Accepted: 11.04.2020 | Published: 17.05.2020

*Corresponding author: Yadevendra Yadav

\section{Abstract}

Aasavikarana is an age-old technique used in Ayurvedic Pharmaceutics. It dates back to "Rig Veda" which indicates the use of Soma and Sura which has been used in different medicinal preparations, surgical procedures and in many chemical and alchemical operations. Asava Arishtas (medical tincture), and Shukta (acidic fermented product) without doubt is one of the most potent medicinal formulations. Among many other reasons, one cause for its extraordinary performance may be the method of phytochemical extraction from it. The technique of microbial maceration of phytochemical extraction is inviting much attention in nutraceuticals due to its high yield, convenient, energy-saving and cost effective. Aasavikarana is a complex pharmaceutical process of microbial maceration and various other chemical processes like fermentation, Maillard reaction, hydrolysis of polymers and formation of antioxidant species. An effort is made to enlighten the process of microbial maceration in Aasavikarana and their effect on formulations in the present article.

Keywords: Aasav-arista, Soma, Maceration, Shukta, Phytochemical, Phenols, Shukta.

Copyright @ 2020: This is an open-access article distributed under the terms of the Creative Commons Attribution license which permits unrestricted use, distribution, and reproduction in any medium for non-commercial use (NonCommercial, or CC-BY-NC) provided the original author and source are credited.

\section{INTRODUCTION}

Aasavikarana is a technique used in Ayurveda which is famous from the period of Rig-veda. Rigvedic people knew fermentation property of this drink is evident from the hymns praising Somarasa. The Shukla Yajurveda describes the formation of two stimulating drinks - Sura- and Parishuta. First time in the Vedas Somarasa was mentioned in the Vedas, was considered the earliest evidence of the use of intoxicants in India. However, in Veda word Soma is for two things, one is Plant juice and another for alcoholic preparation, process by fermentation of juice. The Ninth mandala of the Rigveda is known as the Soma mandala. It entire Shlokas of "Soma Pavamana" (purified Soma) elaborate all thing related to Soma. The drink Soma was prepared, stored and distributed by the Gandharvas [1]. In Samhita era, both alcoholic and acidic fermentation has been discussed in the context of Sandhana Kalpana. It contains both water-soluble and alcohol-soluble active principles of the drug. The basic pharmaceutical principle in Sandhana Kalpana is to extract active constituents of the drug through a biochemical process of fermentation in a mildly self-generated alcoholic medium. This ensures extraction of both water- and alcohol-soluble constituents [2, 3]. In Ayurvedic compendium there are two types of alcoholic fermentation i.e., Sandhana Kalpana- Asava and Arishta. Medieval age Ayurvedic scholar Sarangadhara has clearly defined the difference between both. Asava is prepared by without boiling the drug in water, therefore can be prepared by Hima (cold infusion) or Swarasa Kalpana (Juice/ Must). Though, in Arishta Kalpana, Kwatha (Decotion/Hot infusion) is uses. Charakacharya has described 9 Asava yonis and 84 fermentative products [4]. Susruthacharya has described 11 Asava-arishta and 46 Madya Vargas. Perhaps the word alcohol derived from word Kohala, which time termed by Sushrata for alcoholic beverages [5] Similarly, word 'Cidar' is also derived from Hindi word Sirka. [Sekar-Hebru, Sikera-Greek, Sidre-Old French, Cidar Middle English]. Ashtangahridaya has mentioned for the first time the use of Dhataki Pushpa (Woodfordia floribunda salisb) in fermentation [6, 7]. Max Muller dated as 3000 BC, the Pre-Aryan hill tribes fermented Mahua-flowers (Madhuca indica J. F. Mel) and distilled the liquor. The different terms associated with fermentation in various texts are: Asuta (begetting a newform), Abhisuta (extraction, may indicate extraction from fermented smash), Parisrut ('foaming', 'fermenting', that is, the state of fermenting) and Sandhana (complete absorption of ferment with fermenting material). Except the last term, all other 
terms have a reference in vedic literature [8]. In Ancient time, alcoholic liquors were classified into various categories depending on their applications in alchemical operations: Dasanapasani and Ranjanisura were used in the dyeing operations, whereas, Sarvacarani and Dravanisura were used as solvent. Rasabandhani and Rasampatani were used for purification of mercury.

Advantages of Sandhana Kalpana over other dosage forms depicted in Ayurveda [9]

(i) Longer shelf life without losing its potency

(ii) Palatable and pleasant taste

(iii) More effective

(iv) Accepted by all age groups

Materials required for Aasavikarana are; Dravya Yoni (base material e.g. Fruit or flower etc); Drava dravya (Decoction or Juice), Madhura dravya (Sugar, Honey, Jaggery); Sandhana dravya (Starter for fermentation e.g., Kinwa, Surabija,); Prakshepa dravya (fine powder of herbs for adding flavor and aroma.)

(i) Dravya: The Dravyas can be selected from 9 Asava-yonis ie Twak, Kanda, Saara, Pushpa, Patram, Mula, Phala, Dhanya, Sharkara

(ii) Drava dravya: Mainly, Mrdu dravyas are used in Asava as Hima/Swarasa Kalpana. Kathina dravyas are used in Arishta Kalpana in the form of decoction.

(iii) Madhura dravya: Guda (jaggery), Sharkara(sugar), Phanitha (molasses), Madhu (honey) and Sitopala (sugar candy) are mainly used as fermentable sugars along with working as sweetening agents. The ideal quantity of sugar for fermentation is $40 \%$ as yeast grow well in this condition.

(iv) Sandhana dravya: Dhataki pushpa, Madhuka pushpa and Kinwa/Surabeeja are the common fermenting agents used in Ayurveda. They are the natural carriers of fermentation causing microorganisms. Recent days, dried yeast granules are used to fast the process of fermentation in Aasava-asrita.

(v) Prakshepa dravya: These are the drugs added later to increase the aroma, color and taste of the formulation. It acts as an adjuvant to the therapeutic action of the main drug. Some formulations advocate the use of metals like Swarna and Loha in the form of Bhasma (Ash) which enhances the properties of Sandhana Kalpana.

The mentioned duration of time for fermentation 15 days or 1 month in Ayurveda [10]. In this period, the fermenting vessel is deposited into the earth, heap of grains, horse dung and sometimes exposed to the sun. Likes, Arista, Asava and Sura, similar fermentation products, Aranala, Cukra, Dhanyamala, Kanjika, Sauviraka, Sukta, Tusambu, etc, are also considered potent medicinal drugs [11].

\section{Procedure of Asvikarana}

All the ingredients are mixed together and filled up to $75 \%$ of the container capacity, seal tightly by sandhibandhana (sealing of opening) and maintained at a temperature of about $25-30^{\circ} \mathrm{C}$.It takes about 15 days in summer and about 1 month in winters for the process to complete. The classics mention Jatarasam [12], Vyakta Amla Katukam [13] and Gandha-VarnaRasotpatti as the confirmatory test for Aasavikaranam. Its dosage as mentioned in classics is 1 Pala $(40 \mathrm{ml})$.

\section{Base material for fermentation in Ayurveda}

The process by which sugars are converted to alcohol and carbon dioxide by yeast in the absence of oxygen is known as fermentation. Woodfordia floribunda salisb, is mainly emphasized in the ancient Ayurvedic texts as one of the most important fermentation product, hence the names Madhyhetu and Madakara. Charaka quoted it among the fermenting agents (Asava yoni) [14]. In a recent comparative study on the effect of the addition of yeast (Saccharomyces cerevisiae) and Woodfordia floribunda salisb as fermenting media, it was revealed that the initiation and completion of fermentation in yeast media were faster than that of Woodfordia floribunda salisb mediated fermentation. Fermentation may be delayed because of natural growth and multiplication of yeast cells as well as the role of other microbes in the production of alcohol during fermentation process was conducted [15, 16]. In Another comparative study on traditional methods of preparation of Arjunarista and by microorganisms responsible for fermentation isolated from the flower Woodfordia fruticosa was inoculated to the liquid having mixture of ingredients of Arjunarista. The result of new approach was successful in generating equal proportion of alcohol content. Obviously, the new process prevents the growth of unwanted microbes [17].

Manwer and his team in 2004, isolated the alcohol-producing yeast, Saccharomycopsis fibuligera and Saccharomyces cerevisiae from flowers of $W$. floribunda. They further reported that Saccharomyces cerevisiae produced alcohol more than any other isolated yeast species. Moreover, the uncertainty about $W$. floribunda as source of yeast that useful in fermentation of Asava-Arishta is persistent [18]. Further, Das et al. showed that the flowers of $W$. floribunda contain a significantly high concentration of tannins, (up to the extent of 22\%) and such polyphenolic compounds are liable to enzymatic conversion to simple phenols and alcohol during fermentation. Perhaps, this substantiates the extensive use of W. floribunda fermentation [19]. While, a similar study conducted on Nimbrarista, disclosed that the flowers themselves are not the source of alcoholproducing microorganisms.

Another, edible flower Mahuwa are used to make alcoholic beverage (fermented flower) locally 
called 'Mahuli' in India. [20] Mahua flowers are rich source of sugars $72.9 \%$, proteins $4.4 \%$, Fat $0.5 \%$, calcium $150 \mathrm{mg}$, Iron $15 \mathrm{mg} / 100 \mathrm{gm}$, magnesium, and vitamins [21]. In Ayurvedic pharmaceutics it is also considered as source of fermenting starter. However, Mahua flowers are good source of fermentable sugar. 68-72\% of total sugars, out of which maximum proportion is of reducing sugars is found in Madhuca latifolia L. Sucrose, maltose, glucose, fructose, arabinose and rhamnose are type of simple sugars identified [22]. It is important well-known that, Microbes play a crucial role in fermentation process which finally aids in conversion of carbohydrate sources into alcoholic production and degradation of phytoconstituents into therapeutics content [23]. Both Woodfordia floribunda salisb and Madhuca latifolia $\mathrm{L}$ are naturally providing good source of nutritive media for the growth of microbes. Both contain variety of bacteria and fungus capable to survive in anaerobic condition. The blossoming period of both plants is starting of summer that is ambient time for germination of microbial spores.

Fermentation: The fermentation is derived from Latin word 'Fermentum' that stands for boiling. Fermentation is the process of chemical conversion of organic substances into simpler compounds. Fermentation reaction began with sweet substances and catalysis by certain enzymes. Bioconversion of glucose/sugar to ethanol in the fermentation process is consists of four major unit operations viz, pretreatment, hydrolysis, fermentation, and product separation/distillation.

Microbial maceration: Maceration is a biological process of softening of cell wall of tissue and breaking them into pieces due to osmosis. Ultimately, compounds present inside the cell wall of tissue gets leached out into the liquid (extract). The extract thus obtained contains many of the metabolites such as pigments, phenols, flavonoids, and terpenes [24]. Many microbes are able to produce enzymes, which can degrade the cell wall matrix and can release the bound phenolics [25].

Moreover, maintaining microbial maceration conditions is necessary for the efficient growth of the microbes to macerate and ferment different sources and enhancing the extraction efficiency. Moreover, recent studies reported that the microbial maceration of legumes, cereals, and pulses resulted in extraction of the higher amount of phytochemicals, which possess numerous biological functions such as antioxidant activity and anticancer effects [26] Recently, different researchers have reported that microbial maceration significantly enhanced the soluble total phenolic content of soybean, soybean, black soybean, chickpea, cowpea, bran, black soybean, pea, common bean, kidney beans, wheat koji, buckwheat, barley, wheat, rye, Avena sativa and lotus seeds [27].
Phytochemicals known to have medicinal benefits are considered to be "active ingredients" or "active principles" of natural medicines. A variety of extractions methods are used in practice of the Ayurveda \& all traditional and complementary medicine (TCM) and isolated of natural products are sharing half of the proportion of Allopathic drugs. Extraction is the primary step to separate the desired natural products from the raw materials. The principle extraction method includes mechanical pressing, decoction solvent extraction, microbial maceration distillation method, and sublimation. These methods are used in TCM from the beginning. Their advance versions are Solvent Maceration, Percolation, Soxhlet extraction, Reflux extraction, Pressurized liquid extraction, Supercritical fluid extraction, Ultrasoundassisted extraction, Microwave-assisted extraction and Enzyme assisted extraction etc. Maceration is a very simple extraction method with the disadvantage of long extraction time and low extraction efficiency. It could be used for the extraction of thermo-labile components. Microbial maceration technique is a combination of enzymatic and solvent extraction. Additionally, this method enhances the organoleptic properties and stability [28]. Thick and hard cell wall of crude herbal medicine is made fragile by increasing the fluidity. Water hydrolyzed the Cellulose, polysaccharide and pectin layer of cell wall. The cell of tissue easily bust up then different organelles, pigments and phytochemical are come in solvent. This process is fastened by providing heat. High osmotic fluid of sugar syrup is the first precursor for the maceration. It is also an excellent media for proliferation of fermenting microbes. Hydrolytic enzymes in the fermenting material hydrolyze the starch, and other complex sugar to produce the reducing sugars during alcohol fermentation. Self-generated alcohol is also assisting the extraction of alcohol soluble phytochemicals. Therefore, maceration-fermentation as an essential stage for the natural pigments, volatile compounds, coloring substances (phenolic compounds) and aroma compounds extraction [29]. Most of the coloring pigments and other highly bioactive compounds are located in the skins/ peel of fruits and vegetables. They could be easily extracted by formerly described techniques. During the partially completed of fermentation process sometimes "Maillard reaction" also occurs. This reaction involves the initial condensation of the reducing-end carbonyl group of reducing sugars, ketones or aldehydes and free primary amine group of amino acids, peptides or proteins, or even other nitrogenous compounds. As a result of the occurrence of this reaction, a wide range of compounds, generally termed as Maillard reaction products (MRPs) are formed. In any case, different bioactivities, including antioxidant activity, have been associated to those formed components [30]. A study on effects of Maillard-reacted sodium caseinate (cMRP) and Maillard-reacted whey protein concentration 
(wMRP) to their enhancement of cardiovascular health in ICR mouse and rat models presented some very positive result. Bleeding time was significantly prolonged by Maillard-reacted whey protein concentration (wMRP) equivalent to that of the aspirin group (positive control). Moreover, in vivo study on the acute pulmonary thromboembolism-induced mice overcame severe body paralysis or death in both the wMRP. Particularly, cMRP showed the highest reducing effects on triglycerides, aspartate transaminase, and alanine transaminase. Therefore, cMRP and eMRP have antioxidative defense mechanism that regulated cholesterol synthesis and metabolism. In addition, significant preventive and therapeutic roles of these MRP obtained in the management of the cardiovascular disease [31].

In microbial maceration, different input factors (such as time, temperature, humidity, concentration of the inoculum and other conditions) are playing an important role to determine the efficiency of the process as it influences the efficient growth of the microbes to macerate and ferment different sources and enhancing the extraction efficiency. Different research studies have proved the fact that there is more antioxidant activity as well as more soluble phytochemical content by microbial maceration than conventional extraction methods [32]. The advantage of using microbes is to extract compound from different sources and its simplicity for getting high yields, very easy to handle, low-cost, and low energy consumption [33].

\section{Phytochemical transition in Asava-arista during fermentation}

1. In a comparative study between phytochemical of decoction of Arjuna and Arjunarishta through HPLC-PDA method, it was found that there is an increase in amount of ellagic acid and gallic acid in Arishta compared to decoction [34]. These possess high antioxidant activity [35]. Arjunolic acid and Arjunic acid were not detected in Arishta. The flavonoids (4-oxoflavonoid), quercetin and kaempferol which was introduced into the formulation during fermentation are known to show membrane stabilizing properties $[36,37]$ vasodilation capacity [38] and are found to prevent deposition of low density lipoprotein which are major cause of lipoprotein[39].

2. In a study for estimation of naturally produced water soluble vitamins in different Asavas and Arishtas using liquid chromatography, a good presence of range vitamins B complex was identified [40].

3. In a comparative study between Jeeraka decoction and Jeerakadyarishta, an increase in amount of luteolin and apigenin was present in Arishta compared to that in decoction [41]. Luteolin is a natural flavonoid which possess potent anti-oxidant and anti- inflammatory activities [42].

4. Balarishta and Chandanasava possess two yeasts (Shukta and Schizosaccharomyces pombe) and six bacteria that are species of Bacillus, Paenibacillus, and Brevibacillus. GC-MS analysis indicated that several compounds disappear as a result of fermentation while many are retained. The presence of new phytochemical compounds in the final stages of fermentation could be ascribed from the parent molecules that are either disappeared or retained during fermentation. It suggests the biotransformation of phytochemicals by the mediation of intrinsic microbes. These medicines possess antioxidant activities by the presence of phytochemicals such as phenolics, flavonoids, tannins and phytosterols, wherein bacteria also contribute [43].

Thus, from the above discussion, we can conclude that microbes play a vital role in phytochemical extraction and thus increasing its efficacy. Only few reports are available until date for the extraction of active compounds by Asavikarana and still some part is untouched, which needs to be explored in the coming era.

\section{Merit of Asavaikaran:}

(a) Extraction of phytochemical without boiling. So thermoliable compounds are safely extracted.

(b) The use of ripe fruits or their juices for Asavarista formulation, which could be an alternative use of the large volume of fruit produced in its peak season, is considered to be an attractive way of utilizing surplus and over-ripe fruits [44]

(c) Practicable to convert the fruit, barks, roots and flowers into value-added products.

(d) Microbial maceration is one of the viable approaches which is easy to handle, costeffective, energy efficient, less hazardous and having high extraction rate. Conventional extraction techniques include ecofriendly extraction, hydro-distillation, solvent maceration, soxhlet extraction.

(e) A natural and economical method of preservation of foodstuff.

Asavikarana w.s.r. to microbial maceration: The above-mentioned studies point to be pondered that Aasavikarana is not just fermentation, but it encompasses microbial maceration extraction, water soluble extraction, alcohol soluble extraction and maillard reaction etc and other unknown process. The process of making Kwatha for Arishta and Drava dravya in water for Aasava helps in phytochemical extraction by degrading the cell membrane of the cell (leaching). Fermentation is a biological process produced by yeast, and maceration is a physicochemical 
process which requires the extraction of anthocyanins and tannins to obtain the color and aroma of Asavaarista. Addition of flower of Woodfordia floribunda salisb or Madhuca indica J. F. Mel to the fermentable substance facilitates microbial maceration and fermentation, as they serve as a source for fermentation triggering microbes. Yeast species ferment the formulation and converts complex compound into simple form. Self-generated alcohol formed during fermentation slowly but steadily extracts the active principles. Since the duration of fermentation is long, sufficient time is available for concentration of active principles in the solution. Mostly these compounds are phenols, flavonoids and other active groups. Increase in antioxidant activity of the finished product is due to bioconversion of polyphenols and flavonoids into simple forms of phenols, which are known to have significant antioxidant effects.

\section{CONCLUSION}

Sandhana Kalpanas are the most potent and efficient Ayurvedic Dosage form which are widely used for various therapeutic purposes. Moreover, as they have nutritive values as well as act as an appetizer, their potential usefulness is enhanced. Due to various advantages such as palatability, quick action, the convenience of administration, and longer shelf life, these preparations are preferred by the consumers. The wisdom of our Acharyas can be established as even the postmodern techniques discovered now was base of many of the formulations designed by them. Though the prospects of microbial maceration are under study by modern scientists, its practical application was well established by Aasavikarana. Thus, Aasavikarana is not mere fermentation but a very innovative and efficient method of phytochemical extraction formulated by ancient Ayurveda Acharyas.

\section{REFERENCES}

1. Singh, N. L., Mishra, P. K., Shukla, S. K., Kumar, J., \& Singh, R. (2010). 02. Alcoholic fermentation techniques in early indian tradition.

2. Tripathi, B. (2005). Sharngadharasamhita with 'Dipika'Hindi commentary. Varanasi. Chaukhamba Surbharati Prakashan. Reprint.

3. Prabhakar, R.G. (1998). A Text Book of Bhaisajya Kalpana Edition-1998, 152.

4. Acarya, V. J. J. T. (1941). Charak Samhita with commentary of Cakrapanidatta. New Delhi: Rashtriya Sanskrita Sansthan (Deemed to be University), 31.

5. Trikamji, A. J. (2002). Sushruta Samhita with commentary of Dalhana. Sutra sthana, 194.

6. Murthy, S. K. (2005). Sutra Sthana Verse. Astanga Sangraha of Vagbata. 9th ed. Varanasi: Chaukhambha Orientalia, 111.

7. Paradkar, H.V.(2002). Chikitsa Sthana. 66. 08. Astanghridyam. New Delhi: Rashtriya Sanskrita Sansthan (Deemed to be University), 648.
8. Goyal, P.(2020). Traditional Fermentation Technology, History of Indian Science \& Technology. www.indianscience.org., visted on 20-02-2020.

9. Kaur, H., Kumar, H., Wijayanthamal, M.V.R., Asava \& Arista. (2015). Under umbrella of sandhana Kalpana, Int J.Res. Ayyurved Phar, 6(6), 749-55.

10. Chaudhary, A.K., Kanjiv, L. (2006). Bhaishjya Ratnawali of Govinda Dasji. 1st ed., Vol. 3. Varanasi: Chaukhambha Sanskrit Sansthana, 100(54), 365-70.

11. Sharma, R.P., Meena, M.P. (2017). Bhaisjya Kalpana Vigyan, Jagdesh Sanskrit Pustkalya, Jaipur India, $3^{\text {rd }}$ Edition, 231-61.

12. Acharya, S. (2012). Sharangadhara, samhita, Madhyama Khanda10/77-92,English translation by Prof. K.R. Srikantha Murthy, Reprint edition, Chaukhamba Orientalia, Varanasi, 144

13. Acharya, A., Charaka, S.(2014). Volume II, Chikitsa sthana14/74,English translation by R,K Sharma and Bhagwan Dash, Reprint edition, Chaukhamba Sanskrit Series Office, Varanasi, 597.

14. Woodfordia floribunda salisb. (2017). A backbone herb for all asava and arishta, Nautiyal R, Chaubey S, Tiwari C, Int. J. Ayur. Pharma Research, 5(6), 84-88.

15. Hiremath, S. G., \& Joshi, D. (1991). Role of different containers and methods on alcoholic preparations with reference to Kutajarista. Ancient science of life, 10(4), 256.

16. Kumar, H., Pandey, P. K., Doiphode, V. V., Vir, S., Bhutani, K. K., Patole, M. S., \& Shouche, Y. S. (2013). Microbial community structure at different fermentation stages of Kutajarista, a herbal formulation. Indian journal of microbiology, 53(1), 11-17.

17. Randive, D. S., Sayyad, S. F., Bhinge, S. D., \& Bhutkar, M. A. (2016). Preparation of Arjunārișta Using Microbes Isolated from Woodfordia fruticosa Flowers (Dhayati). Ancient science of life, 36(1), 42.

18. Shodhganga.inflibnet.ac.in/ bitstream/10603/99739 /11 /11- Chapter\%202.pdf, pp-54.

19. Das, P. K., Goswami, S., Chinniah, A., Panda, N., Banerjee, S., Sahu, N. P., \& Achari, B. (2007). Woodfordia fruticosa: Traditional uses and recent findings. Journal of Ethnopharmacology, 110(2), 189-199.

20. Swain, M. R., Kar, S., Sahoo, A. K., \& Ray, R. C. (2007). Ethanol fermentation of mahula (Madhuca latifolia L.) flowers using free and immobilized yeast Saccharomyces cerevisiae. Microbiological Research, 162(2), 93-98.

21. Ward, O. P., \& Singh, A. (2002). Bioethanol technology: developments and perspectives. Advances in applied microbiology, 51, 53-80. 
22. Sikarwar, R. L. S. (2002). Mahua [Madhuca longifolia (Koen.) Macbride]-A paradise tree for the tribals of Madhya Pradesh.

23. Lal, U. R., Tripathi, S. M., Jachak, S. M., Bhutani, K. K., \& Singh, I. P. (2009). HPLC analysis and standardization of Arjunarishta-an Ayurvedic Cardioprotective formulation. Scientia Pharmaceutica, 77(3), 605-616.

24. Azwanida, N. N. (2015). A review on the extraction methods use in medicinal plants, principle, strength and limitation. Med Aromat Plants, 4(196), 2167-0412.

25. Huynh, N. T., Van Camp, J., Smagghe, G., \& Raes, K. (2014). Improved release and metabolism of flavonoids by steered fermentation processes: a review. International journal of molecular sciences, 15(11), 19369-19388.

26. Azmir, J., Zaidul, I. S. M., Rahman, M. M., Sharif, K. M., Mohamed, A., Sahena, F., ... \& Omar, A. K. M. (2013). Techniques for extraction of bioactive compounds from plant materials: A review. Journal of food engineering, 117(4), 426436.

27. Zheng, Z., \& Shetty, K. (2000). Enhancement of pea (Pisum sativum) seedling vigour and associated phenolic content by extracts of apple pomace fermented with Trichoderma spp. Process Biochemistry, 36(1-2), 79-84.

28. Zhang, Q. W., Lin, L. G., \& Ye, W. C. (2018). Techniques for extraction and isolation of natural products: a comprehensive review. Chinese medicine, 13(1), 20.

29. Del Llaudy, M. C., Canals, R., Canals, J. M., \& Zamora, F. (2008). Influence of ripening stage and maceration length on the contribution of grape skins, seeds and stems to phenolic composition and astringency in wine-simulated macerations. European Food Research and Technology, 226(3), 337-344.

30. Kim, E., Chang, Y. H., Ko, J. Y., \& Jeong, Y. (2013). Physicochemical and microbial properties of the Korean traditional rice wine, Makgeolli, supplemented with banana during fermentation. Preventive nutrition and food science, 18(3), 203.

31. Oh, N. S., Park, M. R., Lee, K. W., Kim, S. H., \& Kim, Y. (2015). Dietary Maillard reaction products and their fermented products reduce cardiovascular risk in an animal model. Journal of dairy science, 98(8), 5102-5112.

32. Sharma, B. R., Kumar, V., Gat, Y., Kumar, N., Parashar, A., \& Pinakin, D. J. (2018). Microbial maceration: a sustainable approach for phytochemical extraction. 3 Biotech, 8(9), 401.

33. Demain, A. L., \& Fang, A. (2000). The natural functions of secondary metabolites. In History of modern biotechnology I (pp. 1-39). Springer, Berlin, Heidelberg.
34. Lal, U. R., Tripathi, S. M., Jachak, S. M., Bhutani, K. K., \& Singh, I. P. (2009). HPLC analysis and standardization of Arjunarishta-an Ayurvedic Cardioprotective formulation. Scientia Pharmaceutica, 77(3), 605-616.

35. Mullen, W., McGinn, J., Lean, M. E., MacLean, M. R., Gardner, P., Duthie, G. G., ... \& Crozier, A. (2002). Ellagitannins, flavonoids, and other phenolics in red raspberries and their contribution to antioxidant capacity and vasorelaxation properties. Journal of Agricultural and Food Chemistry, 50(18), 5191-5196.

36. Kaneko, T., \& Baba, N. (1999). Protective effect of flavonoids on endothelial cells against linoleic acid hydroperoxide-induced toxicity. Bioscience, biotechnology, and biochemistry, 63(2), 323-328.

37. Nakagawa, K., Kawagoe, M., Yoshimura, M., Arata, H., Minamikawa, T., Nakamura, M., \& Matsumoto, A. (2000). Differential effects of flavonoid quercetin on oxidative damages induced by hydrophilic and lipophilic radical generators in hepatic lysosomal fractions of mice. Journal of Health Science, 46(6), 509-512.

38. Duarte, J., Pérez, F. V., Utrilla, P., Jiménez, J., Tamargo, J., \& Zarzuelo, A. (1993). Vasodilatory effects of flavonoids in rat aortic smooth muscle. Structure-activity relationships. General pharmacology, 24(4), 857-862.

39. Reed, J. (2002). Cranberry flavonoids, atherosclerosis and cardiovascular health. Critical reviews in food science and nutrition, 42(S3), 301316.

40. Singh, N. K., Sharma, A., Sharma, M., Singh, R., \& Katiyar, C. (2013). Estimation of naturally produced water-soluble vitamins in different asavas and arishtas using liquid chromatography. Journal of Food and Pharmaceutical Sciences, 1(3).

41. Lal, U. R., Tripathi, S. M., Jachak, S. M., Bhutani, K. K., \& Singh, I. P. (2010). RP-HPLC analysis of Jirakadyarishta and chemical changes during fermentation. Natural product communications, 5(11), 1934578X1000501113.

42. Luo, Y., Shang, P., \& Li, D. (2017). Luteolin: A flavonoid that has multiple cardio-protective effects and its molecular mechanisms. Frontiers in pharmacology, 8, 692.

43. Vinothkanna, A., \& Sekar, S. (2018). Influence of intrinsic microbes on phytochemical changes and antioxidant activity of the Ayurvedic fermented medicines: Balarishta

Chandanasava. Ayu, 39(3), 169.

44. Araújo, S. M., Silva, C. F., Moreira, J. J. S., Narain, N., and Souza, R. R. (2011). "Biotechnological process for obtaining new fermented products from cashew apple fruit by Saccharomyces cerevisiae strains," Journal of Industrial Microbiology and Biotechnology, 38(9), 1161-69. 